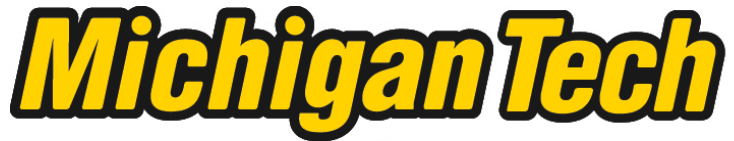 \\ Michigan Technological University Create the Future Digital Commons @ Michigan Tech
}

2013

RESILIENT WOMEN, METISTIC SCIENTISTS: A MULTIPLE CASE STUDY OF HOW WOMEN NEGOTIATE THEIR SITUATEDNESS IN SCIENCE FIELDS

Isidore Kafui Dorpenyo

Follow this and additional works at: https://digitalcommons.mtu.edu/etds

Part of the Rhetoric and Composition Commons

Copyright 2013 Isidore Kafui Dorpenyo

Recommended Citation

Dorpenyo, Isidore Kafui, "RESILIENT WOMEN, METISTIC SCIENTISTS: A MULTIPLE CASE STUDY OF HOW WOMEN NEGOTIATE THEIR SITUATEDNESS IN SCIENCE FIELDS", Master's report, Michigan Technological University, 2013.

https://doi.org/10.37099/mtu.dc.etds/608

Follow this and additional works at: https://digitalcommons.mtu.edu/etds

Part of the Rhetoric and Composition Commons 
RESILIENT WOMEN, METISTIC SCIENTISTS: A MULTIPLE CASE STUDY OF HOW WOMEN NEGOTIATE THEIR SITUATEDNESS IN SCIENCE FIELDS

\author{
By \\ Isidore Kafui Dorpenyo
}

\begin{abstract}
A REPORT
Submitted in partial fulfillment of the requirements for the degree of MASTER OF SCIENCE

In Rhetoric and Technical Communication
\end{abstract}

MICHIGAN TECHNOLOGICAL UNIVERSITY

2013

(C) 2013 Isidore K. Dorpenyo 
This report has been approved in partial fulfillment of the requirements for the Degree of MASTER OF SCIENCE in Rhetoric and Technical Communication.

\title{
Department of Humanities
}

\author{
Report Advisor: $\quad$ Dr. M. Ann Brady \\ Committee Member: $\quad$ Dr. Robert Johnson \\ Committee Member: $\quad$ Dr. Marika Seigel \\ Committee Member: Dr. Carol MacLennan \\ Department Chair: Ronald Strickland
}


To my mother 


\section{Table of Content}

1 Acknowledgements ........................................................................................ vi

2 Abstract....................................................................................................................... vii

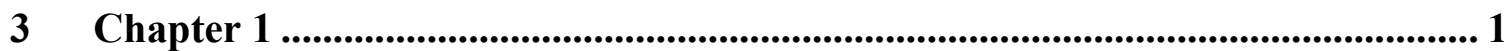

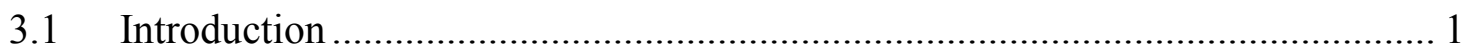

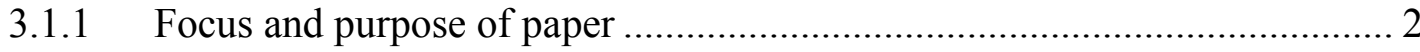

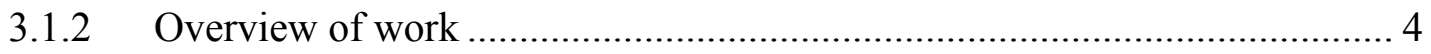

4 Chapter 2 ....................................................................................................................... 5

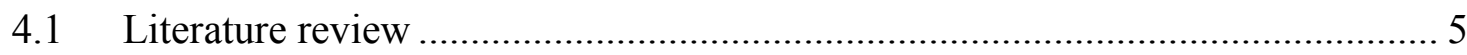

4.1.1 Selections from feminist rhetorical resilience: the ethical ambiguity of

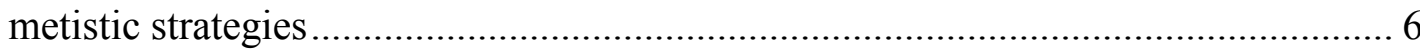

$5 \quad$ Chapter 3 .................................................................................................................... 9

5.1 Epistemological Assumption, Methodology and Methods ................................ 9

5.1.1 Epistemological Assumption ................................................................... 9

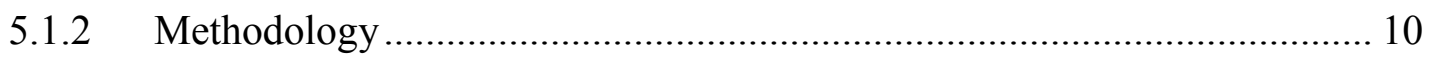

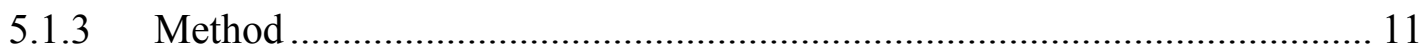

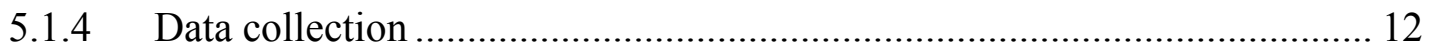

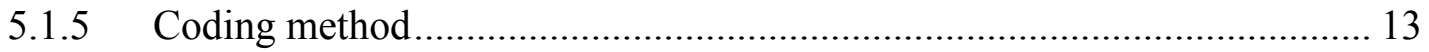

6 Chapter 4 ....................................................................................................................... 15

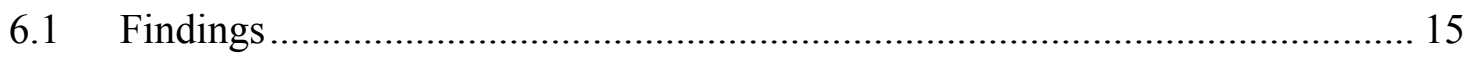

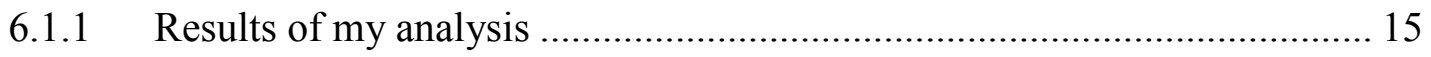

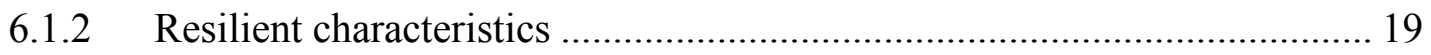

7 Chapter 5 ........................................................................................................................ 25

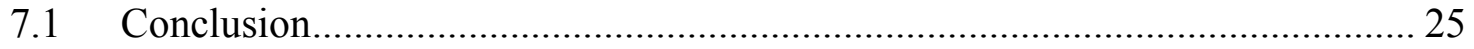




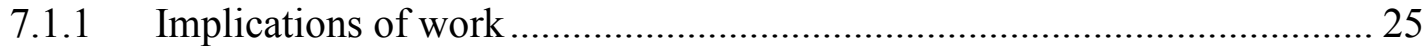

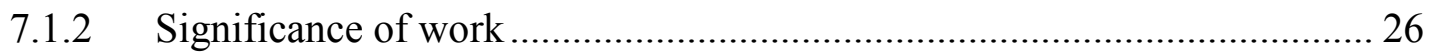

7.1.3 Recommendations for future work .................................................... 27

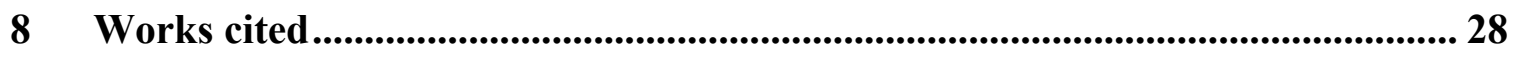

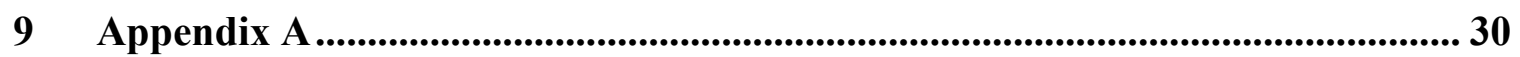

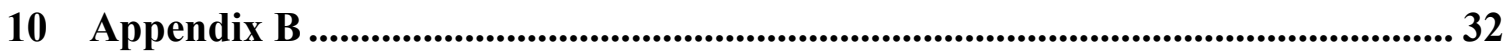

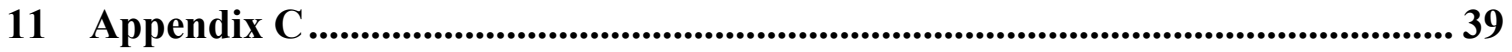




\section{Acknowledgements}

First and foremost, I wish to thank God for how far He has brought me. I could not have made it without His blessings and His protection.

To Ann Brady, my supervisor, I say my gratitude is in abundance. Her feedback, comments and guidance saw me through this journey. Even when there seemed to be no hope and I wished to give up, she urged me on and supported me. I also appreciate the efforts of my committee members. Their final comments strengthened the structure of my work.

Finally, I want to acknowledge my interviewees for their dedication, commitment and interest in my research. This work could not have been possible without them. They devoted their time for the interviews and member checking. I appreciate it. 


\section{Abstract}

The concept of feminist metistic resilience postulates that the voiceless, the marginalized and the minority in societies employ strategies in order to turn tables in their favor. This study presents a qualitative analysis of how women, considered to be the minority, negotiate their situatedness in science fields in order to effect change in their lives or that of the society and why they become successful. By "situatedness," I refer to the everyday life of women as they live and encounter people, society and culture, especially, the life of women who have transcended the culturally stipulated role of women and are excelling in a male dominated field. The study, in different dimensions, conceptualizes the reason for the fewer number of women in science; looks at how scientific methods and practices inhibit the development of women in science; and, finally, interrogates the question of objectivity in science. It becomes apparent, through feminist metistic resilience, that women become successful when they accept conventional practices in scientific arrangements and structures. They accept the practices by embracing and not questioning structures and arrangements that have shaped the field of science and by shifting shapes and assuming different forms in order to adapt to conditions they encounter. Apart from adapting and shape shifting, the women also become successful through environmental and social influences. My analysis suggests that more women can be encouraged to pursue science when women practicing science begin to question structures and arrangements that have shaped the practice of science over the centuries. The overall findings of the research provide implications for policy makers, educators and feminist researchers. 


\section{Chapter 1}

\subsection{Introduction}

I would a thousand times rather have a homely girl...than a learned lady and a wit who would make a literary circle of my house...A female wit is a scourge to her husband, her children, her friends, her servants, to everybody. From the lofty height of her genius, she scorns every womanly duty, and she is always trying to make a man of herself.

--Jean-Jacques Rousseau, (Emile, pg. 349)

I hope that the political awareness generated by the women's movement can and will support young women who today attempt to challenge the dogma, still very much alive, that certain kinds of thought are the prerogative of men.

--Evelyn Fox Keller, ("The Anomaly of a Woman in Physics" pg. 30)

Knowledge of the involvement of women in science from ancient times to the present is scanty. This is probably due to the fact that the practice of science has been the preserve of men. It could also stem from the fact that science as a way of knowing originates from a Western political ideology that valued men's way of knowing more than the ways that women come to know and understand things. "Certain kinds of thought," Evelyn Fox Keller states "are the prerogative of men" and the "representation of the world, like the world itself, is the work of men; they describe it from their own point of view, which they confuse with absolute truth" (quoted in Code ix). The patriarchal kinds of thought that are the prerogative of men are objective ${ }^{1}$ but "all Western cultural narratives about objectivity are allegories of the ideologies governing the relation of what we call mind and body, distance and responsibility" (Haraway pg. 583).

Science or scientific knowledge as is and has been practiced for centuries has assumed an important, special and privileged position in our societies owing to the preconceived notion that what science pursues is putatively self-evident truth and it is objective. Truth "says that which is....This identification of the truth about something, the discovery of what it is, is called 'knowledge,' and this knowledge is called 'science"" (Whitburn pg. 16). A reexamination of sixteenth and seventeenth century reveals that sciences practiced at these times were based on masculine notion of reason and objectivity. It was rooted in the dichotomy that existed in Western thought which valued culture over nature, mind over body, reason over emotion, objectivity over subjectivity, and the public realm over the private realm (Wajcman 5). Since women were almost

\footnotetext{
${ }^{1}$ The term could mean the rational, accurate or unbiased account of the world. It is value-neutral. For more on this term read Situated knowledges by Donna Haraway and The Science Question in feminism by Sandra Harding and what can she know? Feminist theory and the construction of knowledge by Lorraine Code
} 
always identified with nature, body, emotion, subjectivity and the private, the assumption was that they were not fit for the field of science as it is the province of culture, objectivity, reason, mind and public- traits associated with men. If science is objective and true, then it means that only men can pursue it or the man is the only being to be considered scientific.

Science, which has its roots from the Greek word episteme and Latin scientia, stresses knowledge acquisition. It has to do with the inquiry into natural and human phenomena. Science, as received knowledge suggests, is ruled by certain principles (archai), causes (aitiai) and is made explicit with precision in analysis. According to Aristotle, what distinguishes the scientist from other disciplines is his wisdom. Thus the person of science is wise and seeks to understand principles. What the scientist knows is " extraordinary, amazing, difficult and divine..." (pg. 91). Aristotle describes the most exact sciences as "the study of first principles; these principles are the hardest to know because they are "furthest from the senses"” (Atwill pg. 76). Related to the idea of science is technology which has its roots from the Greek word techne. Modern civilization defines technology as applied science. Thus knowledge of one leads to the existence of the other. In this case, the knowledge acquired through scientific enquiry becomes the basis for which technology comes into existence. For instance, knowledge of medicine helps in the development of medicines used to cure human ailment; knowledge of mechanics helps in the production of automobiles; Einstein's theory of relativity, which is scientific, was used to develop the atomic bomb.

Even though science and technology are much related topics, I will focus more on science because of the privileged position that science has assumed in our societies and also because my participants, who are affiliated with science departments, raised issues that are more related to science than technology. I would maintain, however, that there is no clear cut distinction between science and technology when it comes to discrimination against women.

\subsubsection{Focus and purpose of paper}

The phenomenon under discussion is the process by which women, who are considered to be the minority in science, become successful and why they become successful. Success will be defined as having borne the brunt of the misogynist field to attain a graduate student status and a successful academic or research career and contributing to the development of science through research and teaching. In measuring how successful my interviewees are, I draw my inspiration from the dictum "Success is to be measured not so much by the position that one has reached in life as by the obstacles which he [she] has overcome" by Booker T. Washington.

I argue that most women that have been successful in the field of science employ a rhetorical strategy known as resilience: the ability to not only "bounce back" from a traumatic or a disastrous occurrence but also to embrace one's current situation and make it a source of motivation to aid in achieving what one hopes for. This form of resilience is what I associate with rhetorical metis. The adaptive and shape shifting nature of metis 
will be the focus of research. By "adaptive nature," I look at how my interviewees adjust to the conditions that they face in the field and by "shape shifting," I refer to the various forms, characteristics and persona that they assume in order to adapt to the conditions and forces they encounter so that they can effect a change, either for the benefit of society or for individual gains.

My aim in this project is not to indulge in a historical search of women in the field of science. Rather, my intention is to tell, analyze and critique the stories of how women negotiate their situatedness in a male dominated field. By "situatedness," I make reference to the everyday life of women as they live and encounter people, society and culture, especially, the life of women who have transcended the culturally stipulated role of women and are excelling in a male dominated field. It is also my hope that the stories of the successful women will serve as a source of motivation to women who aspire to pursue science. The study also suggests possible ways that policy makers, educators and feminist researchers can help change policies that hog-tie women from studying science.

Perhaps an important concern that arises from the ongoing discussion is whether it is relevant at all to devote our attention to the ways that women come to know and the ways they become successful in science fields. It has become necessary to study women in science and learn how to encourage other women into science fields because "the history of technology [and science] represent the prototype inventor as male (parenthesis mine)" (Wajcman 15) and "each point out, history in general, and the history of technology [and science] in particular have tended to omit the activities of women in part by locating significance primarily in public and political activities and innovations (parenthesis mine) "(Durack 37). Most importantly, institutions that "produce knowledge about women, and position women in societies according to the knowledge they produce, are informed by the versions of and variations on the methods and objectives that received epistemologies authorize" (Code $\mathrm{x}$ ). It is about time that the woman is represented as an agent of knowledge, rational and capable of succeeding in anything she sets her hands on and it is also paramount to turn our attention to what the woman knows, how she knows it, and how she can make public what she knows. I share Lorraine Code's assertion that "women have to be in positions where they can know, if they are effectively to challenge the oppressions that have shaped their lives" (pg. xii).

The historical sketch above provides a vignette of the social and political contexts that have shaped scientific practices. On the whole, social and political contexts did not see women as objective in nature, and thus, assumed them to be unqualified for objective inquiry. Hence the field of science has been tagged misogynist or hostile to women.

Notwithstanding this hostile and misogynist attitude toward women both in society and in the field of science, some twentieth and twenty-first century women have managed to excel in this field. Mention can be made of women such as Evelyn Fox Keller (a physicist), Barbara McClintock (1983 Nobel Laureate) and Rosalind Franklin (biophysicist and X-ray crystallographer) whose love for science and persistence have achieved several feats. These women, in one way or the other, proved to be resilient. 
Their success stories lead to a lot of questions: is there still male dominance in science? Do women value objectivity? Does science still seek objectivity and truth? How do women in science fields define the processes and factors that have contributed to their successes? Do women realize that there can be female perspective to the study of science? Answers to these questions can be found only by asking women themselves. I believe that the women mentioned above and my interviewees were successful only because they developed a mental ability that enabled them to embrace their situations. They saw their situations not as an impediment to their progress but as a resource that motivated them to attain success. In sum, the women adopted rhetorical resilient strategies. In doing so, however, they conformed to conventional scientific practices that give prominence to traits associated with males.

\subsubsection{Overview of work}

This project is organized into five chapters. The first chapter introduces my purpose, focus, my research questions and my hypothesis. Chapter two is the literature review section. I discuss the theories that inform my research. I define feminist rhetorical resilience and focus on one aspect of feminist rhetorical resilience: metistic strategies. Chapter three discusses my methodology. The major methodological approach to this study is qualitative and my method is in-depth interview. The stories of my interviewees become my subject for analysis and critique. Chapter four is the results section. Here, I refer back to the characteristics of feminist metistic resilience that I espoused in my second chapter. I identify a connection or disconnection between resilient characteristics and the traits that my interviewees exhibit. The fifth chapter, which is my conclusion, presents the significance and implications of my project on research, policy and educators. 


\section{Chapter 2}

\subsection{Literature review}

In this chapter, I discuss the major theoretical framework for this project, resilience: the ability to not only "bounce back" from a traumatic or a disastrous occurrence but also to embrace one's current situation and make it a source of motivation to aid in achieving what one hopes for. I also look at how two scholars who contributed to the essays in the book Feminist Rhetorical Resilience cited instances where women used metistic strategies (a form of resilience). The concept of "resilience" has been advanced by scholars from different fields such as psychology, child development, psychiatry and sociology (Buzzanell; Bachay Judith B.; Earvolino-Ramirez; Werner). I rely on the definition espoused by Elizabeth Flynn, Ann Brady and Patricia Sotirin.

In Feminist Rhetorical Resilience, the editors extend the definition of resilience to include concepts such as agency, metis and relationality (Flynn pgs. 7-12). Even though women, or the vulnerable, may exhibit almost all of the concepts in their quest to negotiate their situatedness, I focus on the ways women or the vulnerable use metistic strategies to create change or possibilities of change in the field of science or in their lives. My choice is driven by my belief that metistic strategies embody both agency and relationality. Metistic strategies make available all tools, methods and ways that one needs to be successful in situations that are far beyond the individual's strength, imagination and reasoning. More importantly, metis is "a discursive technology" employed to overturn essentialized gender constructions (Brady pg. 211). For instance, in Classical Greek mythology, the cunningness of Metis was used in defeating the Titans by the Olympians; Her powerfulness is celebrated by Detienne and Vernant when they assert that "without the help of the goddess [Metis], without the assistance of the weapons of cunning, she controls through her magic knowledge, supreme power could neither be won nor exercised nor maintained" (58); Metis is relational, never works alone but with the help of three powerful forces: tuche (luck), kairos (opportunity to succeed) and techne which Atwill suggests represents "...the power of transformation that metis enables.... Metis is timely; it is flexible and very practical (Dolmage ""Breathe Upon Us an Even Flame": Hephaestus, History, and the Body of Rhetoric" 121). Thus the person with "metis perceives the world of tuche, harnesses kairos, and has the ingenuity required to think of cutting and building the tiller" (Dolmage ""Breathe Upon Us an Even Flame": Hephaestus, History, and the Body of Rhetoric"). More importantly and as will be revealed in the articles that I have selected, the person with metis "in contrast to the linear progress of rational thought, never goes forward in a straight line but is always weaving from side to side and looping back on itself (qtd. in Dolmage "Metis, Metis, Mestiza, Medusa: Rhetorical Bodies across Rhetorical Traditions" 5-6). Thus the person with metis, shifts shapes and adapts to situations in order to create awareness or effect a change.

It is evident from the above examples that metistic strategies include all the tools that women use in their quest to be successful in a male dominated world. They can be 
cunningness or deceit, love, passion, resistance, knowledge or intelligence, adjusting to situations to remain in motion and or it can be embracing who they are and hoping for a better future. A person with metis does not give up and I would argue that it is this unyielding attitude combined with adaptability and shape shifting nature that makes women successful in science fields.

But, my question is: did the women I interviewed combine metistic tools such as forethought, resourcefulness, opportunism to open up possibilities of success or change in science fields? Can my interviewees use metistic strategies to change the way science is done? Did they in any way look for opportunities to over turn tables in their own favor? Or are my interviewees aware of inhibiting tendencies of scientific practices? Resilience in the form of metis, then, implies that the individual channels all the tools that metis makes available to create a change or to look for possibilities of creating change. The two articles discussed below give us the practicality and the ethical ambiguities that metistic resilient strategies evoke.

\subsubsection{Selections from feminist rhetorical resilience: the ethical ambiguity of metistic strategies}

In constructing an argument, I look to how contributors to the essays in the book Feminist Rhetorical Resilience, cite instances where women who employed rhetorical metis managed to change situations to advance their individual personal gains or advanced the needs of society. Even though selections in this chapter employ resilient methods, the two articles I discuss identify how women employed metistic strategies to 1) advance personal and societal goals and 2) create awareness of inhibiting forces in their societies and countries. The selected stories contribute to the multifaceted nature of metistic resilience strategies. In one instance, women use positive means to create awareness or change and in another, women use negative means to achieve set targets.

A form of resilient metistic strategy that raises ethical issues is identified when a section of women in Turkey surreptitiously or cunningly unified to resist and subvert a culture that forbids them from engaging in premarital sex. The women presented in Goksel's "Virginity and Hymen Reconstructions: Rural, Migrant Women as Agents of Literate Practices in Turkey" adapt to the world and societal norms they encounter through hymen reconstruction. These Turkish women used all means available to adapt to situations they confronted. In trying to adapt, these women shifted shapes and transcended their boundaries from not virgins (bakire degil) to virgins (bakire). "They [Turkish women] manipulate the mechanisms of virginity to create alternative spaces for themselves (parenthesis mine)" (ibid pg. 104) and this is a kind of metistic resilience. These women embraced their situations as women, analyzed their current situations and realized that a change could be effected in their lives. That change could only come about through action. Through their actions, they mocked the tradition that made virginity a prerequisite for women. The women proved to be unyielding in their pursuit to change a culture that inhibited their development when they partook in an activity done "in an outpatient procedure performed under local anesthetic" (Goksel pg. 95). By "connecting 
with others" through conversations, these women made larger cultural changes and as a result these "women became agents of their own lives" (ibid pg. 92). They also redefined and expanded the concept of literacy as "the ability to read and write" to literacy as "critical thinking and authorship" (Goksel pg. 92). Thus the women make us aware that we do not only encounter the world around us through reading and writing. We can also encounter the world through interpretations of the events that we encounter. One does not acquire critical thinking through formal education, but, one can acquire it through constantly engaging in a dialogue with the world. They were ready to bear pain to effect a change in their lives and in the society. The actions of these women provide a quintessence for scholars to interrogate the ethical conundrums that metis presents: is it good to use a negative concept to advance a just social cause?

Metistic resilience can also be used ethically to advance a good cause and this is present in the article "Vandana Shiva and the Rhetorics of Biodiversity: Engaging Difference and Transnational Feminist Solidarities in a Globalized World, " by Eileen E.Schell. Strategies of metistic resilience, shape shifting, forethought, embracing current situation and adaptability are employed to solve global environmental crisis by an Indian environmentalist. Like the women discussed in the article above, Shiva proved to be kairotic and resilient when she "recognize[d] and seize[d] opportunities for social change even in the most oppressive situations" (ibid pg. 33). She chanced on two events in India to pursue her environmental advocacy work:

- The 1984 genocide in Punjab over changes in agriculture.

- A gas leakage from a Union Carbide pesticide in Bhopal, India, that killed 3000 people and injured a lot others (ibid Schell pg. 35).

Shiva becomes metistic in her mode of approach when she critically sought for answers to the occurrences. The questions she posed: "Why has agriculture gone so violent? And "Why are we so dependent on pesticides" (Schell pg. 35) helped her to interpret and understand the world around her. Shiva's interpretive nature (a metistic characteristic) enabled her to use symbolic action-words, images, signs-and direct action to persuade multicultural audiences to pay attention to biodiversity and damaging environmental conditions (pgs. 32-33) around the globe.

Added to the use of symbolic action, Shiva used persuasive action. She becomes metistic in her resilience to effect a change both locally and globally when she shifted shapes by using approaches that combined ecofeminisms and transnational feminisms, Ghandian philosophy of nonviolence and noncooperation developed from Hindu principles (Schell pg. 38) to make people aware of the need to save the environment. Shiva's resilience paid off as her efforts "have influenced agricultural trade negotiations, shaped international policymaking, and sparked coalitions between diverse groups of farmers, environmentalists, public-interest scientists, and concerned citizens (pg. 49). What this article makes concrete is that metistic resilience always comes against an external force and when this external force appears, the person with metis chances on an 
opportunity to effect or initiate a change or create awareness. This story makes us aware that metistic resilience as a method can be used ethically to advance good ends.

These stories presented in this chapter go a long way to talk about certain characteristics of metistic resilient strategies. The stories foreground the idea that metistic strategies can be used to advance personal gains and or to advance the needs of the society. Resilience, in the form of metis,:

- Is interpretive and effects change by subverting institutions.

- Is exigent, kairotic and productive.

- Shifts shapes and adapts.

- Changes the status quo.

- Manipulates through negative and positive means.

These are the characteristics that will form the basis of my discussion of whether contemporary female scientists are aware of the inhibiting tendencies of scientific practices. Based on these characteristics, I want to find out if, in their quest to be successful in their chosen fields, in their resilience, women scientists, especially my interviewees, employ metistic strategies. To what extent do they employ them? And how metistic are they?

The next chapter discusses the method, methodology and epistemological assumptions I used to study how women employ metistic strategies. I discuss qualitative methodology and in-depth interview as one of the ways that can help us know how women employ resilient strategies. The findings generated from the methodology I employed will be used vis-a-vis the characteristics that I have outlined in this chapter to discuss metistic resilience. 


\section{Chapter 3}

\subsection{Epistemological Assumption, Methodology and Methods}

Taking gender as the starting point of inquiry...is a necessary but not a sufficient condition of feminist methodology, for feminism has as its ideological goal the overturning of patriarchal assumptions and practices that render women's experiences invisible and undervalued

--Patricia Sullivan (Methods and Methodology in Composition Research, pg. 50)

In my second chapter, I laid down resilient characteristics that women exhibit when they encounter powerful forces. The focus of this project is to look at how women negotiate their situatedness ${ }^{2}$ in a male dominated field. In this chapter, I present an overview of the methodology, method and epistemological assumptions I used to achieve the goal of the project. Following Devault and Harding, I make a distinction between "research methods" - particular tools for research, "research methodology" -theorizing about research (Devault pg. 31) or the "principles, process and procedures by which I approached the research problem and conducted my research" (Molla pg. 31) and "epistemology" - the study of how and what we can know (Devault pg 31).

\subsubsection{Epistemological Assumption}

The main epistemological approach employed in my research is phenomenology. With the aid of this approach, I studied "the structure of various types of [women experiences] ranging from perception, thought, memory, imagination, emotion, desire, and volition to bodily awareness, embodied action, and social activity, including linguistic activity (parenthesis mine)." In my research, I decided to use phenomenological assumptions based on the reasons that phenomenology:

- Seeks to gain a deeper understanding of the nature and meaning of everyday experiences.

- Focuses on researching conscious experiences (capta) rather than hypothetical situations (data). (Orbe pgs. 606-8)

With a phenomenological approach to investigating the ways that women negotiate their situatedness in science fields, I set out to collect data through interviews; I reduced the

\footnotetext{
${ }^{2}$ By "situatedness," I make reference to the everyday life of women as they live and encounter people, society and culture, especially, the life of women who have transcended the culturally stipulated role of women and are excelling in a male dominated field

${ }^{3}$ http://plato.stanford.edu/entries/phenomenology/\#1
} 
interviews into essential themes and categories; and I interpreted the themes. As described below, I used three coding methods to analyze my data. The following sections explain how I used phenomenology at each stage of my research.

\subsubsection{Methodology}

One area of study that has adopted the use of phenomenological assumptions in conducting research work is qualitative research methodology. Qualitative researchers have used this approach as the "principle, process and procedures" (Molla pg. 31) by which research problems are approached and conducted. To the qualitative researcher, reality is relative and there is also the assumption that there should be an interactive relationship between the researcher because "knowledge is within the meanings people make of it... and is gained through people talking about their meanings" (Molla pg. 36; Creswell pg. 19) and the "researcher has to approach the researched in their natural setting and respect their multiple perspectives" (Molla pg. 32). This project seeks to look for ways that women negotiate their situatedness in male dominated fields. Embarking on a research such as this one means looking for ways to empower women. The best way to empower is to give women the voice to speak to their experiences. With my goal in mind, I chose a methodology that is "gentler and that humanizes both the researcher and the interviewee. Allowing people to "talk back"'(ibid 26). Talking back gives a voice to the silenced because they have the chance to interpret their worlds and how they encounter the world around them. Phenomenology, thus, offered me the opportunity to listen to how women in science fields encounter powerful forces and what motivates them to be successful in their various fields of study.

Feminist researchers have used phenomenology and qualitative methodology to recover the lost voices of women in societies (Cannon, Higginbotham and Leung pg. 449). I argue that the methodological approach to this project is feminist. It is feminist in the sense that the research "include[s] women's lives and concerns in the accounts of society... and support (s) changes that will improve women's status" (Devault pg. 29) in the field of science. In this regard, attention is shifted from things that men know about women to things that women know about themselves. This feminist methodology provides women the chance to give a fuller and more accurate account of the society (qtd. in Devault pg. 33). In a way, through feminist methodologies, women "talk back" to society by uncovering the numerous ways that women have been subordinated through masculine ideologies. I locate my work as feminist methodology because it shares commitments to two goals of feminists:

- My project does the work of excavation by shifting the focus of standard practice from men's concerns in order to reveal the locations and perspectives of women. It is undeniable that the aim of feminist research has been to find what has been ignored, censored and to reveal ideological mechanisms that have made women invisible (Devault pg 32).

- My project uses a participatory research methodology that supports research of value to women, and this could lead to social change or action beneficial to women (ibid pg. 33). Through in-depth interviews, I gave some women in science 
the opportunity to rethink about the way science is practiced and also to look at ideologies that have shaped the practice of conventional science.

\subsubsection{Method}

The method (in-depth interview) is also qualitative and phenomenological because it studies a group of people (women scientists) in order to understand their expertise, their worldview and qualities of their culture (Lindlof pg. 103) and settings. It is a kind of a pentimento ${ }^{4}$ that tries to make visible women's voices and ideas that have been buried by societal norms. I found this method very appropriate because it afforded my interviewees the opportunity to speak their minds in a "natural" setting-three interviews were conducted in the offices of my interviewees and one in the library. Questions were structured to aid the interviewees to reflect on their daily practices ${ }^{5}$. I asked interviewees to talk about what motivated them to study science, how their parents reacted when they revealed their intentions to study science. I also asked them to talk about their relationships with their male counterparts and also about how they feel about the fact that there are fewer number of women pursuing science. Thus this method gave the individual interviewees the chance to "connect the everyday troubles individuals face to public issues of power, justice and democracy" (qtd. in Rubin pg. 25). Qualitative method (interview) is also appropriate because I believe that "a more open, loosely structured research method is necessary to learn about women, to capture their worlds, their concepts, and the importance they place on the events in their world" (Rubin pg. 26). For instance, even though I had questions for my interviewees, sometimes I did not even follow the order of questions. Neither did my interviewees do that. Philomena for instance chose to answer question 16 and connected that to question 3. I sometimes asked questions outside the already prepared questions. This loosely structured nature of the interview, I believe, gave my interviewees the opportunity to relate to their daily lives and experiences. My project can, however, not claim to capture objective reality, but issues and subjects have been fairly represented through the use of multiple methods.

As it is necessary, every research work seeks to persuade audiences that it is credible and this can be achieved when researcher carefully chooses research site, participants and topic. Credibility can be enhanced when the researcher chooses participants who are experienced, "knowledgeable, whose combined views present a balanced perspective, and who can help one test one's emerging theory" (Rubin pg. 64). Based on these criteria, I visited (with the help of my supervisor) the various pages of the science departments in my school and randomly selected seven women professors in the various departments. I sent them initial emails to schedule an appointment for further discussions about the research I was undertaking. Out of seven emails sent out, four

\footnotetext{
${ }^{4}$ An Italian term for "repentance" and it is used in this project to describe a situation where something that has been painted out of picture becomes visible again, creating something new.

${ }^{5}$ See appendix $\mathrm{C}$ for interview questions.
} 
women replied and expressed their interest in the research. I contacted them, discussed the research purpose and focus with them and we scheduled an appointment. These women professors came from different science departments; math, physics, biology and forestry. While selecting my interviewees, I was guided by these questions:

- How long have these women been practicing in their fields?

- What are their professional statuses? Are they full Professors, Associate Professors or Assistant Professors?

In my view, if one were a full Professor, then it meant she has been in the field for a long time and has distinguished herself national, Associate has been in the system for quite a while and Assistant is new in the system. My final four participants met these categories. Two of my interviewees were full Professors; one was an Associate and the other an Assistant Professor. One of the full Professors was retired. The four interviewees whose profiles are provided in the appendix section of the paper are Dorcas, Philomena, Georgina and Mercy. I believe that the women selected represent the various experiences that women encounter in their zeal to succeed in science fields. What binds them together is the fact that all four respondents have graduated with $\mathrm{PhD}$ degrees in their various fields; they are lecturing, researching and contributing to the development of science. I contacted the women professors to seek their official consent of participation and then I proceeded to secure an approval from my Institutional Review Board (IRB). Therefore, I can say that this research meets ethical requirements and is credible.

\subsubsection{Data collection}

The major research method used to collect my data was: interview-"conversations in which a researcher gently guides a conversation partner in an extended discussion" (Rubin pg. 4). Interviewing, I believe, is a method that can help women talk about what they know, how they know it and how to make public what they know. Interviewing helped me to understand the perspective of women, retrieve their experiences and also helped me to gain expert information on how they negotiate their situatedness in a male dominated field. Individuals "tell their stories as they see fit and, in so doing to achieve some coherence in shaping their own understandings" (Lindlof pg. 174) or interviews become "vehicles for exploring people's explanations" (ibid). In telling their stories, they better understand their situations and strategies to encounter their world. On the other hand, the interview would also give my interviewees the opportunity to talk about reasons that have led to the smaller number of women in science fields. This is an avenue for self reflection and self disclosure.

After interviewing my interviewees, I listened and transcribed the audio recorded interviews. After transcription, I went back to the interviewees for member checking ${ }^{6}$.

\footnotetext{
${ }^{6}$ This is when data, analytical categories and interpretations are tested with interviewees or members from whom data were gathered.
} 
They had the opportunity to listen to the audio and read the transcript to make sure that what they said were captured accurately and fairly.

\subsubsection{Coding method}

Coding is important to the qualitative researcher because it opens up more avenues for inquiry. Coding helps the researcher to identify and "develop concepts and analytical insights through close examination of, and reflection on, field note (interview) data" (Emerson pg. 175). The goal of this process is to "produce coherent, focused analyses of aspects of the social life that have been observed and recorded, analysis that are comprehensible to readers who are not directly acquainted with the social world at issue" (qtd. in Emerson pg. 171). Following traditional coding method, I went through several processes to get my coding done (Emerson pg.172; Rubin pg. 200; Saldana pgs. 73-84). I worked at reducing the raw information. For this process, I read and reread the transcribed interviews to highlight some major and interesting statements made by interviewees. I followed that by summarizing every response given to each question by the interviewees. After summarizing, I reread the transcripts again and used words and phrases to label and name the highlighted transcription. I combined three coding processes when labeling. First, descriptive coding; second, initial coding, and third process coding.

Descriptive coding process "summarizes in a word or short phrase...the basic topic of a passage of a qualitative data" (Saldana pg. 70). Its importance is to assist the reader to see what I saw and to hear what I heard on the field; initial coding refers to the coding process that breaks "down qualitative data into discrete parts, closely examining them and comparing them for similarities and differences (ibid pg. 81), and process coding uses "gerunds to connote action in the data" (Saldana pg. 77). Descriptive process contributed words and phrases such as "Knack for math," "change social context," and "support from family;" initial process helped me to get to important concepts that run through my data. Topics such as, "shape shifting," "negotiating situatedness," and subtopics as "networking and connections," and "family members" were conceived through initial coding, and process coding contributed such labels as "researching in field," "questioning things" and "noticing discrimination." These concepts and labels were influential to the project. After assigning labels to my transcripts, I wrote down the recurring ideas on one side of the paper and those ideas that did not occur often on a different side of paper. I worked more with the recurring ideas but I bore in mind the importance of the non-recurring ideas as well.

After I was done reducing the transcripts to recurring and non recurring ideas, I went back to read my paper to find out those categories that I would want to work with in my paper. I came up with four different categories:

- Adaptability

- Shape shifting

- Environmental or social influences

- Policy statements 
In a tabular form ${ }^{7}$, I defined these categories and wrote down their characteristics and how to identify them in my reduced data. The results or findings will be the subject of discussion in my next section.

${ }^{7}$ I present the table in chapter 4 


\section{Chapter 4}

\subsection{Findings}

\subsubsection{Results of my analysis}

The analysis generated four major thematic categories and I will discuss how they relate to the characteristics of metistic resilience later in this chapter. The themes and categories as they emerged from my coding are outlined in the table below. The next section of the paper presents a description of these thematic categories. See appendix B for detail of how categories emerged from the interviews.

Table 4.1

Thematic categories and their characteristics

\begin{tabular}{|c|c|}
\hline Categories & Defining characteristics \\
\hline Adaptability & $\begin{array}{l}\text { By adaptive nature I look at how women } \\
\text { scientists adjust to the conditions that } \\
\text { they face in the field } \\
\text { Embracing who you are } \\
\text { Knowing yourself and finding what you } \\
\text { love to do }\end{array}$ \\
\hline Shape shifting & $\begin{array}{l}\text { Shape shifting, I refer to the various } \\
\text { forms, characteristics and persona that } \\
\text { they assume in order to adapt to the } \\
\text { conditions and forces they encounter } \\
\text { Talk about skills, resourcefulness, } \\
\text { qualities that make them different from } \\
\text { others }\end{array}$ \\
\hline Environmental or social influences & $\begin{array}{l}\text { This would look at the moments that have } \\
\text { helped them to pursue science } \\
\text { Social factors that have helped them to } \\
\text { succeed } \\
\text { Relationships (familial, friends, mentors } \\
\text { and networks) } \\
\text { Being aware of their challenges }\end{array}$ \\
\hline Policy statements & $\begin{array}{l}\text { What they think can be done to help } \\
\text { women succeed }\end{array}$ \\
\hline
\end{tabular}




\subsubsection{Adaptability}

Elements of adaptability emerged in all four interviews. I define adaptability as how women scientists embrace their identities and adjust to the conditions that they face in the field. Even though they are women, they do not practice science based on conditions that will better favor their conditions as women and those of other women. Rather, they follow structures and procedures that have been established as norms for the field of science. All four interviewees approach science the way their male colleagues do and they had no ill feelings about the practice.

In order to find out how adaptive they are, I asked three questions: What kind of qualities, attributes and skills does one need to succeed in your field? How do you deal with the fact that there are more men than women in your various fields? And, Sandra Harding (Philosopher of science) and Fox Keller (Physicist) hold the view that structures that operate in science fields work against women. What do you think?

In response to the question about the kinds of qualities that are valued in their fields, Philomena believes the "quantitative aspects and observational skills or background are really important and with many things you would have to have an inquiring mind" and Mercy assets that people in math "need to be able to think in a certain way. They would have to have a mind that is able to process things in a certain way...there is something to do with having a little bit of talent for it but I think it is mostly hard work... being able to focus... on what needs to be done and putting a lot of effort..." and Georgina says that:

If you separate math from science, I guess asking questions a lot. I would attribute to...I think that linear processing and this is pretty analytical but I think it is the linear processing that I enjoyed...I always liked puzzles and so I loved working with just puzzles and my parents, I think they made us question things a little bit more but not from a critical stand point.

All four scholars accepted the fact that one has to have an inclination for math; or one must have an inquiring mind; or one must be smart; or one must be able to process things objectively. Again all four interviewees accepted the fact that one must love what she/he is doing. These qualities are not only for women, but are established norms that one would have to follow if one wants to succeed in the field and any other endeavor regardless of gender. These women scientists, in their zeal to succeed, embraced the scientific tradition that they find themselves in. Almost all four researchers are involved in rigorous academic research that employs conventional scientific practices. The adaptive nature of my interviewees attests to Harding's claim that "in order to succeed as scientists, ... women usually had to force their lives as closely as possible into life cycles designed to accommodate the lives of men in patriarchal societies" (Harding pg. 23). 


\subsubsection{Shape shifting}

It is important to stress that this feature of shape shifting recorded the least number of occurrence among the categories. By shape shifting, I refer to the various forms the interviewees assumed in order to adapt to the conditions and forces they encounter. It could be inferred from this definition that shape shifting goes hand in hand with adaptability. In this regard, I look at the various identities that my interviewees assumed in their quest to negotiate their situatedness in science fields. The most obvious form of shape shifting is employed by Mercy. She makes a case that:

I mean I always kind of feel pulled when I am here. I feel like I should be home making sure I can manage the house, manage kids, making sure meals are done at the right time, there is grocery, the kids are going to school, everything else. Doctors appointment so I kind of feel pulled when I am here. When I am home sometimes I feel pulled... I should be doing this, I should be making sure that this exams is done, I should be answering students emails... so it's hard... but I think I sort of separate the two. So when I am here I just try and focus on here, when I am home I focus on home

Philomena and Georgina exhibit minor traits of shape shifting.

\subsubsection{Environmental or social influences}

This theme emerged the most in almost all of the analysis. All four interviewees made allusions to various social and environmental factors that encouraged or discouraged them in their pursuit for knowledge in the science fields. They responded to the questions: How do you define processes and factors that have contributed to your successes? And what are the social processes that lead women toward or away from careers in science? The various influences as coded include: family members, mentoring, networking or connections, discrimination against women, men finding it difficult to communicate with women and vice versa and women against women.

My interviewees made allusions to a lot of social or environmental influences. One of such influences is the family. Philomena believes that the home environment plays a major factor in determining what one will become in the future. According to Philomena, "for any area that you find you want to go into related to your early upbringing and what kind of support you've got and how the STEM areas were viewed in your family...." Mercy also says that:

"Family has given me a lot of support and encouragement both when I was a student and ... also having my position. When I was a student my parents were very supportive and helped me out by doing everything they could to help me as far as when I was a student before I got married and I lived at home with them and they just always took care of// as when I was a kid you 
know...they do my laundry, cook meals for me and do whatever it takes to make things easier for me and also once I got married..."

Dorcas also says, "I think family is a big thing that makes it more difficult for women to be successful...." These quotes make us aware that family has both positive and negative influences on individuals who want to achieve higher goals.

\subsubsection{Policy statements}

Here, I make mention of the various ways that my interviewees think women can be helped to take up careers in the sciences. They responded to the question: what can be done to encourage women to take up careers in science fields? I would say that policies that my interviewees enumerated are inextricably linked to the influences that have made them successful in one way or the other. If the policies are linked to the influences on my interviewees, then we can argue that these policies follow conventional ways of doing science. The very conventions that I argue work against the development of women, a detailed discussion of this category will be provided in chapter five. My interviewees suggest the following as strategies that can be employed.

Georgina believes that policy makers and stake holders should:

Talk to them [young women] more. Talk to them. Go out and talk to them about interesting things that they could do... I think talk to them about the possibilities, bringing them into experiencing that, finding the things that they've always loved to do...

And Philomena says:

If you want to increase the number it is what level so people are looking at stuff from all levels and I have mentioned that if you want to be working at a big impact you have to go through K-3 to $4^{\text {th }}$ grade and not only have stuff at school but it is also in the home environment.

As stated earlier in this chapter, these categories discussed above will be used in relation to resilient characteristics I outlined in the literature review. In the next section of this paper, I discuss how the findings help us to understand metistic resilience. Are women in science metistic based on these categories? For the purposes of my audience and my project, I restate that feminist metistic resilience:

- Is interpretive and effects change by subverting institutions.

- Is exigent, kairotic and productive.

- Shifts shapes and adapts.

- Changes the status quo. 
- Manipulates through negative and positive means.

The underlying question based on these characteristics is: do my interviewees exhibit traits of metis? Or which traits of metis do my interviewees exhibit? I point out here and now that one most important thing we would like to consider is: feminist rhetorical resilience is about creating change and possibilities of change. In essence, a person with metis adapts to a particular situation or shift shapes in order to adapt to a situation so that $\mathrm{s} /$ he can initiate a change (either for individual gains or for the benefit of society).

The instances of feminist resilience cited in chapter two provide guidelines for this discussion. The women in the two articles discussed, interpreted their situations and realized that they needed to initiate a change because their circumstances were not the best. In one instance, women in Turkey found a way to subvert a culture that forbids them from engaging in premarital sex; and in another, words, images and signs and direct action are used to persuade multicultural audiences to pay attention to biodiversity and damaging environmental conditions. These incidents give alternative sides to the person with metis. A metistic individual could advance individual or societal goals. These instances also bring out the ethical implications that metistic strategies evoke. Is it good to use deceit or manipulation to advance your personal means? I discuss the characteristics as they relate to the interviewees below.

\subsubsection{Resilient characteristics}

Having described the thematic categories, I now discuss how the categories relate to the resilient characteristics I outlined in the second chapter. The underlying question based on these characteristics is: do my interviewees exhibit traits of metistic resilience and to what ends? These characteristics also provide a lens for us to interrogate the questions I posed in the introductory section of this report. Thus this section will also answer these questions: is there still male dominance in science? Do women value objectivity? Does science still go for objectivity and truth? How do women in science fields define the processes and factors that have contributed to their successes? Is there a women's perspective to science? Can science be redefined and reformed to meet women's perspectives?

\subsubsection{Metistic person Interprets and effects change by subverting institutions}

What does it mean to be interpretive? And what does it mean to effect a change? In my view, these two concepts go hand in hand. One is considered interpretive when that person can analyze his or her situation. The Turkish women I discussed in my literature review section are perfect examples of interpretive individuals. Interpreting or analyzing your situation means becoming aware of your environment and asking whether what you see can be changed for your personal gains or that of the society. Thus the Turkish women, though not educated, came to the realization of their environments and situations. They thought about the fact that they could do something to better their lots and those of their society. To back their assertions, they looked for ways that they could 
encounter or better still over turn the dominant force-traditions that inhibited their development. By looking for alternative ways, these women subvert a powerful repressive institution (in this case, tradition). Can my interviewees be considered as interpretive? Do they affect any change by subverting their institutions?

Three out of the four women I interviewed accepted the fact that they identify male dominance in their fields. The fourth person who mentions that gender distribution is 50/50 comments that academic positions are heavily weighted towards males. It is good to know that these women have identified male dominance in their various fields but do they think about how male dominance might affect the way they do science? Have they questioned assumptions about how the ideologies that have shaped science might affect how science is practiced? I believe that these are some of the questions that an interpretive person would want to ask. These questions will expose people to their environments and their situations.

It is, however, saddening to note that these are not what my interviewees are concerned about. Questioning structures and institutions bring about some form of revelation and the revelations will lead one to take an action to effect a change be it for individual gains or societal gains. Because these women do not question structures, they do not take steps to initiate changes in their respective fields.

I stated at the beginning of this chapter that I cannot confidently claim that my interviewees are metistic because they do not initiate a change. This echoes Whites argument that "women are reluctant to put themselves forward or to protest their being left out...." The remedy as stated in this article is "not necessarily more individual boldness, but must include new institutional arrangements and programs which do not depend on individual initiative" (White pg. 414). A resilient woman, I would argue, will look for negative or positive avenues to create or initiate a change in her life or the life of others in the society, but my interviewees hardly look for such avenues. In a sense, one could say that they do not question structures in science and they find it unfathomable to think about the fact that the structures encumber their success. In response to the question whether male dominance could be a factor to some of the structures that operate in science, Mercy "does not think about it" because "that is what it is;" Dorcas did not notice it until later in her career life, and Philomena asks "when that is the only structure that has been presented and you are in college, how would you know that there is supposed to be another structure that you are supposed to have,...? This is the way it is."

These women have adapted to the situations they find themselves because, they, in a way, think there is no other way to do what they are doing. In this case, they will feel reluctant to voice their concerns and will find it difficult to question institutional arrangements. The inability of my interviewees to question structures and political ideologies that shape science implies that reformation of science will take quite some time. I believe that it will take concerted efforts of two forces; external forces represented by parents, colleges, peers and internal forces represented by practitioners. When women in science start questioning institutional arrangements and structures, they will recognize 
ideological powers that shape their fields and they can initiate a change, a change that can encourage other women to take up careers in science fields.

As Epstein states, "the barriers of women's advancement and achievement are not merely a function of prejudice or incapacity. The structures or professions, narrow and inflexible as they often are, may create limits which are largely unintended" (quoted. in White pg. 415). Sandra Harding admits that personality traits (abstract thought, physical interaction with environment) that young men require to be successful in science are the traits that are cherished in science (pg. 28).

It appears these traits have not changed and are still the hallmark for scientists. When I asked my interviewees the values that are cherished in their fields, Georgina states that:

trying to be objective in what you see and don't have preconceived ideas...be an active listener, meaning...listening to people and what they have to say... but that is acquired over time but I think that is really a key and not giving your opinion until somebody asks for your opinion...I think the visual is very important and seeing things that others might not see and listening especially if you are going to be answering questions about things that occurred in the outdoors //in forestry...I think having a knowledge base to understand how things function at least.

Philomena responds that the values cherished in biology are values for all and not just for a group of people. The biologist must love what he/she is doing, have to observe, think concisely, must have facility with quantitative analysis and the person must be a good communicator. The mathematician as Mercy puts it "need[s] to be able to think in a certain way. They would have to have a mind that is able to process things in a certain way...there is something to do with having a little bit of talent for it but I think it is mostly hard work... being able to focus... on what needs to be done and putting a lot of effort...." Dorcas is the only person who states that there are no specific values cherished in physics.

These comments point to the fact that my interviewees do not practice science any differently from their male counterparts. Based on the responses to the questions I asked, and, based on what an interpretive person must possess, I cannot say that my interviewees are interpretive and that they work at subverting established institutions. I can say that interpretation or questioning assumptions opens a way for metis to operate-positively or negatively. It is ironic, however, for my interviewees to state that for one to be successful that person must have an inquiring mind or that person must have a knowledge base to understand how things function. Yet, my interviewees hardly question the structures that rule science. 


\subsubsection{Metistic Person is Exigent, Kairotic and Productive}

Recognizing and seizing opportunities to effect a change at an opportune moment is what a person with metistic resilience embodies. Kairos signifies "the exact or critical time, season, opportunity" (qtd. in Atwill pg. 57). One can recognize opportunities and act at a critical time when that person is interpretive, when that person questions and finds ways to effect a change. The critical or opportune moment plays a major role in every reformation process.

How kairotic are my interviewees? Do they make good use of the dominant discussion that calls for more women in science to effect a change or look for possibilities of change? It is an undeniable fact that discourses of the moment call for ways to encourage women into science fields. Even though policy makers and stake holders are calling out for more women to study science, Mercy believes we should let women be and not force them to study science. "...we focus so hard on trying to get women into the field and get them to do this or that we just don't let them be who they are and that is a shame and it's sad" Mercy retorts. By this comment, Mercy, fails to be kairotic because she does not encourage liberators to use the dominant argument of the moment to effect a change. Georgina and Philomena on the other hand, can be labeled kairotic. Georgina believes that policy makers should keep talking to the youth and keep talking about the need to encourage women to pursue science. Thus, her argument is not different from the ongoing discussion that seeks to encourage women. Philomena also adds that policy makers should find a consistent message. Georgina and Philomena agree with other stake holders that call for more women to pursue science. Both Georgina and Philomena have tried their best to be good mentors to their students. They provide equal opportunities for female students to compete with male students by providing equal access to laboratory and by sponsoring students to attend conferences. I acknowledge the good mentorship roles that Philomena and Georgina play. However, I argue that they do not train young women to practice science differently. The young women are mentored to perceive science as value-neutral and objective. A typical case of new wine poured into old wineskin.

\subsubsection{Metistic Person Shape shifts and often adaptable}

Adaptability and shape shifting are two of the categories that emerged in my analysis. I mentioned in my description section that these two categories go hand in hand. The category of shape shifting was the least identified and in majority of cases, my interviewees did not recognize they were shape shifting. I define adaptability as how women scientists embrace their identities and adjust to the conditions that they face in the field and by shape shifting, referred to the various identities the interviewees assumed in order to adapt to the conditions and forces they encounter in the field of science. In cases that shape shifting was identified, it existed because my interviewees wanted to negotiate between their lives as mothers, wives and as academicians. I stated earlier in this chapter that Mercy was the only person who employed what I will call metistic shape shifting. She distinguishes two forces that the woman scientist would have to deal with. The first of the pulls has to do with the family and her wish that she could keep and manage her 
home. She laments that whenever she is at work she feels the pull to be at home to take care of her children. "I mean I always kind of feel pulled when I am here. I feel like I should be home making sure I am managing the house, managing kids, making sure meals are done at the right time, there is grocery, the kids are going to school, everything else. Doctor's appointment so I kind of feel pulled when I am here [school].

By not asking questions about the structures and arrangements in science, my interviewees have proved to be adaptable, but, not to the extent of initiating a change for the benefit of society. One shift shapes in order to adapt to the situations. Is it always the case? In most cases my interviewees adapted to their situations without having to shift any shapes.

It is worthwhile to ask whether my interviewees shifted shapes or adapted to their various fields to effect a change. I would say that even though my interviewees employ characteristics of shape shifting and adaptation, they fail to create change or see possibilities of change to the structures of science and they fail to question how science is practiced. However, they adapted to scientific practices in order to advance their personal goals.

\subsubsection{Metistic Person Transforms}

Changing the status quo (transformation) implies making changes to existing ideas, beliefs, structures and arrangements or transcending stipulated norms, beliefs and practices. I would say that by succeeding in the field of science, my interviewees have managed to break the myth or narrative that sees the woman as a human without an inquiring mind. The interviewees state that qualities that one has to exhibit in their various fields are not qualities for a particular group of people. They are qualities for all. But to what extent do they make structural changes or changes to arrangements in their various fields? I can argue that my interviewees barely change the status quo because they hardly question the institutional arrangements that rule science. Again, changing the status quo calls for an interpretive mode of thinking and asking questions. One can only change a status quo when that person recognizes there is something to change. Sad to say, but, my interviewees do not recognize the need to change scientific practices.

\subsubsection{Metistic Person Manipulates through negative and positive means}

I would say that my interviewees never employed negative means in their quest to succeed in science fields. Manipulation-using fair (positive) or unfair (negative) means to effect a change to aid one's purpose or the purpose of the society- is a metistic resilient strategy. This trait of metis opens a space for scholars and ethicists to discuss the ethical implications of metistic strategy to achieve a set target or to effect a change. The story of the Turkish women gives us much to think about when we are discussing how people can positively or negatively achieve a set target. This trait always raises the questions: "to what extent can metistic strategies be employed?" and "who is to employ metistic strategies?" should the person think about ethics before he/she employs metis or should 
the person think about the end results rather than means to achieve the results?" In most cases, people who employ negative means recognize they are coming against forces they cannot positively encounter. The Turkish women used manipulations to subvert a repressive institution. In this example, these women recognized they could not use positive means. My interviewees followed the stipulated rules and practices in their various fields. It could mean that these interviewees did not employ any negative means because they found nothing wrong with the structures they were working within.

However, I can say that my interviewees employ manipulation any time they mentor students, especially female students in the field of science. My interviewees, psychologically and professionally, present science to their mentees as value-neutral and objective. The students mature in the field thinking that science cannot be practiced in a different way. Science is value-neutral and objective. In this case, even though my interviewees use manipulative means, they do not affect any changes to the field of science because they do not present science in a different way. 


\section{Chapter 5}

\subsection{Conclusion}

My conclusion will be based on the connections I have drawn between resilient characteristics outlined in chapter two of this project and the findings from my interview. I discuss the implications of my work, its significance and recommendations for future research.

\subsubsection{Implications of work}

This work has major implications for research and teaching. It also offers policy makers the chance to critically analyze science curriculums and how best to accommodate the claims made by feminist scholars. Policy makers must take a closer look at how current structures in science inhibit the development of women. Finally, I would say that the onus lies on educators to encourage interdisciplinary studies in various departments. Teachers should make available to their students readings that will help their students to appreciate feminist concerns and interests and students should be educated to welcome feminist concerns. One issue that this project raises is that there remains a lack of awareness about the inhibiting tendencies of conventional scientific practices. Teachers shape and socialize students in a lot of ways and they can use their influence in this regard. Feminist literature and readings about women should be made available to students. When this is done, students and teachers will develop broader perspectives on issues.

The findings of the research also confirm no differences exist between males and females in mental ability with regard to abstract reasoning or mathematical ability. The findings are in contradistinction to the assumptions that males are better than females in regard to abstract reasoning. This also confirms and makes concrete Virginia Valian's claim that "samples of the U.S. population as a whole show no overall differences in mathematics test scores" (Valian pg. 83).

I have stated that science has assumed a privileged position in the society because it is believed to be value-neutral and it goes for absolute truth. A few scientists do not cling to this assertion. Dorcas for instance, is skeptical about this claim. She decided to pursue science because she had thought that science provided a "definite answer" to problems. She became aware that that was not the case when she learned about the "uncertainty principle" in physics. Again, Dorcas brings to question the concept of objectivity in science when she asserts that "we have a certain preconceived notion about things and design experiments the way they would yield the results that we expect to see..." Apart from Dorcas, the remaining three interviewees hold firm that science is objective. Philomena, for instance, believes that women are subjective and the subjective part of women can be relevant in human related sciences but not a science like forestry. The subjective part of science, according to Philomena, is not good. She makes the claim that: 
if you put too much of your ideas into what is going on then maybe you are going to miss what the true function is of a tree growing and what that interactions actually is and what is influencing the tree, [to think of an example] so I think yes and no depending on the field. I think objectivity is very important.

\subsubsection{Significance of work}

The significance of this project is three fold. It has opened a space for researchers to investigate feminist claims about science. Responses to questions about the structure of scientific practices suggest that women scientists (at least my interviewees) are not aware of the inhibiting tendencies of scientific methods. It appears that this sense of "political awareness" that feminists would want to generate has not yet sunk into the minds of some women scientists. For instance, feminist scholars, such as Harding and Fox Keller, have posited several reasons that inhibit the development of women in the field of science. Harding states that:

- Structures that operate in the fields work against women (ibid 28).

- The content of what is taught in science education is flawed because it is based on the ideals of boys (Harding 31). Content of what is taught is also shaped by the social practices of the field and the society.

My interviewees doubt the structures that operate in science inhibit women from pursuing science. They go to the extent of saying that women are not the only group of people faced with attrition. Men drop out of science fields as well for the same reasons females drop out. Do we then doubt the veracity of the claims made by some feminist scholars? We do not have to gloss over these claims, but, the concerns raised should provide a lens and motivation for scientists and other scholars to investigate the structures of science. This calls for a reflection on science as it is practiced. It is also not erroneous to say that my interviewees objected to the claims made above because feminists have only raised issues in the theoretical level but are not following up on issues they have raised. I call on feminists scholars to intensify their awareness campaigns.

In addition, my interviewees reject the claim made by critics of science, such as Harding and Wajcman, that the subjective part of women such as emotions should be accepted in science. My interviewees agree that science cannot go for anything else than objectivity. According to my interviewees subjectivity has no place in science.

The final point of significance is that I have been able to make audible the voices of women in the field of science. We have an idea of what women know, how they know and how to make public what they know. We have also been able to answer whether women do science differently from males. 


\subsubsection{Recommendations for future work}

Given the results of my research project, I recommend that work be done in two different levels. First, more research should be conducted to test the veracity of the claims that feminist scholars make. Even though my interviewees rejected claims about how male dominance affect the practice of science, I would say that researchers still have to work more in this area to find out the truth or falsity of issues raised both by my interviewees and by feminist researchers. This is where my work falls short. I interviewed only four women in a very small university. The sample size of this project is very small. Four is not enough to make a conclusive claim about how women employ metistic strategies to negotiate their situatedness in science fields. Sample size could be increased and if possible, future studies could include interviewees from other universities. I also interviewed women in academe. It would be appropriate to interview women scientists in government institutions, private institutions and research institutions where women scientists work hand in hand with males.

Finally, science teachers and heads of departments should encourage interdisciplinary approach to studies in the various colleges and departments. Interdisciplinary approach will open a way for people to identify multiple perspectives to issues. Teachers in various departments should make available readings that project feminist issues and ideals in their classrooms, at meetings, conferences, homes and gatherings. Various science curriculums should be reviewed to ascertain the truthfulness or falsity of feminist claims. This means that teachers should also have adequate knowledge of feminist issues so they can represent claims of feminists appropriately. 


\section{Works cited}

Women, Science and Technology: A Reader in Feminist Science Studies. Ed. Wyer Mary, Mary Barbercheck, Donna Giesman, Hatice Orun Ozturk and Marta Wayne. second ed. New York: Taylor and Francis Group, 2009. Print.

Aristotle. Nichomachean Ethics. Trans. Irwin, Terence. Second ed. Indianapolis: Hackett Publishing Company, Inc, 1999. Print.

Atwill, Janet M. Rhetoric Reclaimed: Aristotle and the Liberal Arts Tradition. Ithaca: Cornel University Press, 1998. Print.

Bachay Judith B., Pamela A Cingel. "Restructuring Resilience: Emerging Voices." Affilia 14.2 (1999): 162-75. Print.

Brady, Ann. "Interrupting Gender as Usual: Metis Goes to Work." Women's Studies (2003): 211-33. Print.

Buzzanell, Patrice M. "Resilience: Talking, Resisting, and Imagining New Normalcies into Being." Journal of Communication 60 (2010): 1-14. Print.

Cannon, Lynn Weber, Elizabeth Higginbotham, and Marianne L. A. Leung. "Race and Class Bias in Qualitative Research on Women." Gender and Society 2.4 (1988): 449-62. Print.

Code, Lorraine. What Can She Know?: Feminist Theory and the Construction of Knowledge. Ithaca: Cornell University Press, 1991. Print.

Creswell, J.W. Qualitative Inquiry and Reseach Design:Choosing among Five Approaches. sage, 2007. Print.

Detienne, Marcel, and Jean P. Vernant. Cunning Intelligence in Greek Culture and Society. Chicago: University of Chicago Press, 1991. Print.

Devault, Majorie L. "Talking Back to Sociology: Distinctive Contributions of Feminist Methodology." Annual Review of Sociology 22 (1996): 29-50. Print.

Dolmage, Jay. "'Breathe Upon Us an Even Flame": Hephaestus, History, and the Body of Rhetoric." Rhetoric Review (2006): 119-40. Print.

---. "Metis, Metis, Mestiza, Medusa: Rhetorical Bodies across Rhetorical Traditions." Rhetoric Review (2009): 1-28. Print.

Durack, T. Katherine. "Gender, Technology, and the History of Technical Communication." Central Works in Technical Communication. New York: Oxford University Press, 2004. 35-42. Print.

Earvolino-Ramirez, Marie. "Resilience: A Concept Analysis." Nursing Fprum 42.2 (2007): 73-82. Print.

Emerson, Robert M.; Fretz Rachel I.; Shaw Linda L. Writing Ethnograpgic Fieldnotes. second ed. Chicago: The University of Chicago Press, 2011. Print.

Flynn, Elizabeth A, Sotirin Patricia, Brady Ann, ed. Feminist Rhetorical Resilience. Utah State University Press, 2012. Print.

Goksel, Iklim. "Virginity and Hymen Reconstructions: Rural, Migrant Women as Agents of Literate Practices in Turkey." Feminist Rhetorical Resilience. Ed. Flynn, Elizabeth A, Sotirin Patricia, Brady Ann. Logan, Utah: Utah State University Press, 2012. 90-109. Print. 
Haraway, Donna. "Situated Knowledges: The Science Question in Feminism and the Privilege of Partial Perspective." Feminist Studies 14.3 (1988): 575-99. Print.

Harding, Sandra. Whose Science? Whose Knowledge? : Thinking from Women's Lives. Ithaca, New York: Cornell University Press, 1991. Print.

Keller, E. Fox. "The Anomaly of a Woman in Physics." Women, Science, and Technology: A Reader in Feminist Science Studies. Ed. Wyer Mary, Mary Barbercheck, Donna Giesman, Hatice Orun Ozturk and Marta Wayne. Second ed. New York: Taylor and Francis Group, 2009. 23-30. Print.

---. Reflections on Gender and Science. New Haven and London: Yale University Press, 1985. Print.

Kirsch, Gesa, and Patricia A. Sullivan. Methods and Methodology in Composition Research. Carbondale: Southern Illinois University Press, 1992. Print.

Lindlof, Thomas R. and Taylor Bryan C. Qualitative Communicative Research Methods. Thousand Oaks, California: Sage Publications Inc., 2011. Print.

Molla, Tebeje. "Towards Understanding Epistemological Assumptions of History Teachers Educators: My Experience with Phenomenological Enquiry." Educational Research Journal (2010): 27-45. Print.

Orbe, P. Mark. "Centralising Diverse Racial/Ethnic Voices in Scholarly Reseach: The Value of Phenomenological Inquiry." International Jornal of Intercultural Relations (2000): 603-21. Print.

Rousseau, Jean-Jacques. Emile. Middlesex, England: Echo Library, 2007. Print.

Rubin, J. Herbert and Rubin, S. Irene. Qualitative Interviewing: The Art of Hearing Data. Second edition ed. Thousand Oaks, California: Sage Publications Ltd., 2005. Print.

Saldana, johnny. The Coding Manual for Qualitative Researchers. Thousand Oaks, California: Sage Publications Inc, 2009. Print.

Schell, Eileen E. "Vandana Shiva and the Rhetorics of Biodiversity: Engaging Difference and Transnational Feminist Solidarities in a Globalized Word." Feminist Rhetorica Resilience. Ed. Flynn, Elizabeth A, Sotirin Patricia, Brady Ann. Logan, Utah: Utah State University Press, 2012. 30-50. Print.

Valian, Virginia. Why So Slow?: The Advancement of Women. Cambridge, Massachusetts: The MIT Press, 1999. Print.

Wajcman, Judy. Feminism Confronts Technology. Pennsylvania: The Pennslyvania State University Press, 1991. Print.

Werner, Emmy E. "Resilience in Development." Current Directions in Psychological Science 4.3 (1995): 81-85. Print.

Whitburn, Merrill D. Rhetorical Scope and Performance: The Example of Technical Communication. Stamford, Connecticut: Ablex Publishing Corporation, 2000. Print.

White, Martha. "Psychological and Social Barriers to Women in Science." Science, New Series 170.3956 (1970): 413-16. Print. 


\section{Appendix A}

\section{Profile of my interviewees}

I introduce my interviewees. I talk a little bit about who they are, what they do and the various departments that they belong to. These interviewees whose stories and experiences were my focus of analysis are: Dorcas, Philomena, Georgina and Mercy. It is important to note that the names provided are pseudonyms.

\section{Dorcas}

With a background in astrophysics and elementary particles and an interest in the study of gamma and cosmic rays, Dorcas is housed in the physics department in a Midwestern research institution in the United States of America. She received her diploma at a university located in the southern part of Germany in 1996, a place she went to because as an undergraduate, she did an internship at a research facility called DESY (Deutsches Elektronen-Synchrotron). Her interest in that research motivated her to move from a university in the North Rhine-Westphalia region to another research institution in southern Germany. She got her degree doing a simulation on a project called Next Linear Collider. She decided to pursue a PhD from the same university but this time she worked on a project that was involved with an experiment called OPAL (Omni-Purpose Apparatus at LEP).

Dorcas became interested in science (physics) primarily because she had the inclination for math and also because she felt science or physics provided a definite answer. Two movies inspired her more to pursue physics: the first was a documentary which was title "The End of Innocence." This documentary showcased an interview with a German physicist who worked on the German atomic bomb project. She wanted to understand the technology (atomic bomb) that shaped our world. The second was her awareness of the fewer number of women in the field of physics. She wanted to try it out and find out if she would be able to do it.

\section{Philomena}

Philomena has always been interested in biology and she took part in science fairs and went to college intending to be a scientist. She is presently an environmental microbiologist in the same university as Dorcas and her current research deals with turning waste or residuals into bio-products and also looking at antibiotics degradation or remediation. She has been practicing science since 1971.

Philomena got into science because it was a strong part of her family and she was encouraged to pursue it by her family. Her source of motivation was her immediate family. Her father, grandparents and aunt were physicians. 


\section{Georgina}

Georgina is a forester and has been practicing since1973. She is a retired Professor. Her research focuses on the ecology of wetlands and riparian areas within the Upper Great Lakes Region.

She could trace her interest in science and forestry back to camping. Apart from camping, she was interested in math, asking questions, working with puzzles and things that involve linear processing of data.

\section{Mercy}

Mercy is a mathematician interested in combinitorics. Her research is in graph decomposition and combitorial designs. She got her PhD in 1995 from a Midwestern University in the United States of America, a place she received both her undergraduate and master's degrees. She is presently teaching and researching in the same university.

Her interest in science could be traced back to high school when she won a scholarship to attend the Midwestern University. Algebra was fun to her so she chose to study mathematics. 


\section{Appendix B}

\section{Categories and how they emerged}

\subsection{Adaptability}

As mentioned in the text, this category emerged in all four interviews. They responded to the questions: What kind of qualities, attributes and skills does one need to succeed in your field? How do you deal with the fact that there are more men than women in your various fields? And, Sandra Harding (Philosopher of science) and Fox Keller (Physicist) hold the view that structures that operate in science fields work against women. What do you think?

\section{Georgina}

Responding to the question of values that are cherished in the field of forestry, Georgina states:

trying to be objective in what you see and don't have preconceived ideas...be an active listener, meaning...listening to people and what they have to say... but that is acquired over time but I think that is really a key and not giving your opinion until somebody asks for your opinion...I think the visual is very important and seeing things that others might not see and listening especially if you are going to be answering questions about things that occurred in the outdoors //in forestry...I think having a knowledge base to understand how things function at least.

Added to the above qualities is a person's ability to crunch numbers and being outside in the outdoors. She states that:

I was good in math in high school, that was the one thing that I excelled at//my father was really good at math.... What I did was to work with people that worked the industry and academia and just really like crunching numbers and just really enjoy that and really enjoyed the diversity and really enjoyed teaching.

If you separate math from science, I guess asking questions a lot. I would attribute to//I think that linear processing and this is pretty analytical but I think it is the linear processing that I enjoyed//I always liked puzzles and so I loved working with just puzzles and my parents, I think they made us question things a little bit more but not from a critical stand point.

She also believes it is very true that structures inhibit the development of women and especially in the field of academics, how faculty are evaluated will be considered one 
of the structures that stymie women. She believes that "we don't set up structures for respecting everybody and we don't ask for expectations of our students to treat everybody equal."

\section{Philomena}

The qualities cherished by biologists are not isolated qualities but values that cut across all discipline. Philomena responds that the first thing to do if you want to succeed is to really "like what you are doing. If you don't like what you are doing, you probably are not going to stay long or succeed. You have to observe, you have to think concisely, you have to be a good communicator, in many cases you would have to be able to get along with people" but the "quantitative aspects and observational skills or background are really important and with many things you would have to have an inquiring mind."

To the third question on the structure of science, she responds, "when that is the only structure that has been presented and you are in college, how would you know that there is supposed to be another structure that you are supposed to have, right? This is the way it is." According to Philomena, if science does not go after facts, then it is not science but something else.

\section{Mercy}

People in math:

need to be able to think in a certain way. They would have to have a mind that is able to process things in a certain way...there is something to do with having a little bit of talent for it but I think it is mostly hard work... being able to focus... on what needs to be done and putting a lot of effort...

The appropriate way she deals with male dominance is not to think about it. She does not think about it because "it is what it is. That is fine with me."

She objects to the fact that structures that operate in the field of science further advance masculine ideologies. She thinks "Maybe it was that way before long time ago. I really don't think it is like that anymore."

\section{Dorcas}

Dorcas is skeptical about the values that are cherished in her field since there are no stated values that must be adhered to. She talks about the fact that schools of thought propose that a physicist must be knowledgeable about a lot of things but this has proven to be a disadvantage to some other people. In spite of these uncertainties, she believes that what motivates one to be successful is what she called the 3P's: patience, persistence and positive thinking. Values she learnt from her advisor.

As regards how she deals with the dominance of men in her field she responded that she did not notice that initially until she started attending meetings and coming to the 
realization that sometimes she was the only female around. She also started noticing when she realized few women register for a math course she was teaching. She hardly commented on the second question because she felt she did not know enough about it.

All four scholars accepted the fact that one has to have the inclination for math, or one must have an inquiring mind or one must be smart and you have to be able to process things in a certain way.

\subsection{Shape shifting}

\section{Mercy}

She exhibits the most obvious form of shape shifting. The form of shape shifting she adapts stems from her willingness to adjust to two forces that influences her personality as a scientist and a career woman. According to her:

I mean I always kind of feel pulled when I am here. I feel like I should be home making sure I can managing the house, managing kids, making sure meals are done at the right time, there is grocery, the kids are going to school, everything else. doctors appointment so I kind of feel pulled when I am here. When I am home sometimes I feel pulled \{laughs\} I should be doing this, I should be making sure that this exams is done, I should be answering students emails//so it's hard... but I think I sort of separate the two. So when I am here I just try and focus on here, when I am home I focus on home. Not//you know...first it wasn't like that but the more kids I have had the more I have realized that I would have to do that and just keep them separate and so I can focus all my time when I am at school at/on my research and my teaching; when I am at home I can focus my time on my family.

\subsection{Environmental or social influences}

The various influences as coded include:

\section{Family members}

Familial relations were greatly valued by my interviewees. Three out of the four interviewees accepted the fact that family especially parents have really been influential.

\section{Philomena}

Philomena believes that the home environment plays a major factor in determining what one will become in the future. To her, she became interested in science because it was encouraged in her family. She believes strongly that "for any area that you find you want to go into related to your early upbringing and what kind of support you've got and how the STEM areas were viewed in your family...." She adds that: 
The reason why I got into science was that this was a very strongly encouraged in my family... based on studies and work that we have done here, you have to change the home environment, you have to get the parents to realize that this is an acceptable area, my parents//my father was a physician and they were $100 \%$ behind all these things and we did a lot of stuff with nature and science and it was logical.

Philomena also stresses that the fewer number of women in the field revolve around kids and significant others. In most cases, both men and women say that "We want to have a family, we want to have a time to do things, we don't want to be working all the time, we don't want to miss our kids growing up...."

\section{Mercy}

Mercy would also accept the fact that her

"Family has given me a lot of support and encouragement both when I was a student and ... also having my position. When I was a student my parents were very supportive and helped me out by doing everything they could to help me as far as when I was a student before I got married and I lived at home with them and they just always took care of// as when I was a kid you know...they do my laundry, cook meals for me and do whatever it takes to make things easier for me and also once I got married..."

She laments that:

"I mean I always kind of feel pulled when I am here. I feel like I should be home making sure I am managing the house, managing kids, making sure meals are done at the right time, there is grocery, the kids are going to school, everything else. Doctors appointment so I kind of feel pulled when I am here [school]." She accepts that it is not easy to be a mother and a career woman. It is also important to note that whereas Mercy talks about the fact that she has had a supportive husband, Philomena wished that she had someone who would take care of the home, do the dishes. She wished she had a supportive husband.

\section{Georgina}

She has this to say about family: "I guess being a first child [she laughs]. I am the first of 10 kids so that was a big contribution. I guess the parents also helped, my parents...." She remembers that when she gained admission to pursue her $\mathrm{PhD}$, she "and I ended up borrowing a couple of 1000 dollars from my dad." Not only did dad give her money, she also stressed that "my father was good at math." 


\section{Dorcas}

Dorcas enumerates a number of factors that militate against women in physics. She says that "social processes [sighs] eeeemm, so I think family is a big factor, it is difficult to have a family and be successful and find a partner who is willing to have a flexible schedule ...."

\section{Mentoring}

Almost all the interviewees acknowledged the fact that mentoring is a good thing.

\section{Dorcas}

Dorcas talked about how her advisor who doubled as her mentor helped her to connect to people. Dorcas asserts that "role models are important. I think role models are extremely important to see that somebody can be successful and can also have a family." She believes that a role model should be "somebody who understands the problem you are having in the field. So public role models are certainly important but role models inside the field you are working at can also be important."

\section{Georgina}

Georgina also acknowledges the fact that she had interesting male role models. Commenting on how women deal with male dominance she says "I think it is just mentoring too, it really helps."

\section{Philomena}

She believes that apart from family, "hooking up with people who have been mentors..." has been helpful.

\section{Mercy}

Of all four interviewees, Mercy is the only person who did not mention the role that mentoring plays in the success of an individual.

\section{Networking or connections}

Related to the idea of mentoring is networking or connections; what Philomena will refer to as "hooking up with people" and Flynn et al will call "the web of relationship." Three out of four interviewees recognize the role that hooking up played in their successes.

\section{Dorcas}

Dorcas would owe a lot of her successes to her advisor. She talks about the fact that she has been fortunate because "I had people who stood behind me and you know when you are applying you need people to write letters of recommendation for you...." She did not only have people who wrote recommendations for her, she also had "connections." Her second job at a research lab came out of a connection, and with the help of someone she 
met at an NSF review, she was granted an interview at Stony Brook. "Connections" according to Dorcas are "important."

\section{Philomena}

Philomena does not down play the role of networking. According to her it is important that you are going to establish relationships outside... and I think I am very fortunate for both males and females who have been very supportive and people who went through different kinds of things whether or not they have difficulties and they are ready to help and give back to people coming along

The quotation above defines Philomena's second sense of being fortunate. At one point she was fortunate because she had a supportive family and the other sense, she is fortunate because she has people who are very supportive. Philomena started her career off by hooking up with some guys who were well established. She used their laboratory and they are very good friends.

\section{Georgina}

Georgina also admits that "the friends" she met helped her a lot.

\section{Mercy}

She says nothing about hooking up or networking.

\subsection{Policy statement}

They responded to the question: what can be done to encourage women to take up careers in science fields? I would say that policies that my interviewees enumerated are inextricably linked to the influences that have made them successful in one way or the other.

\section{Philomena}

Philomena believes that the most reliable means to getting women into science would come from the home. Added to the family, Philomena challenges policy makers when she states that:

If you want to increase the number it is what level so people are looking at stuff from all levels and I have mentioned that if you want to be working at a big impact you have to go through K-3 to $4^{\text {th }}$ grade.

The next thing you do is to hit different levels in K-12 and we have a lot of programs here where you would send the engineers and the scientist out there to work with the teachers, you bring them here to do things, try to get them get educated for the range of things 
that are possible//you have to keep reinforcing it all levels through college you know the kinds of programs that you have, you know mentoring them and realizing that there are different learning styles and different attitudes that people are coming in with

\section{Georgina}

In addition to changing attitudes of people, Georgina believes that the social context should be changed. She believes that the social context holds the notion that "it is not good to be a scientist and it is not good to be a smart woman... it is not good to be too driven to succeed." The only way to avert this situation is to:

Talk to them more. Talk to them go out and talk to them about interesting things that they could do....Start talking about what really matters you know//to me politics is really important because it does frame your relationships and things that you do but I think it is also good to talk about science at a social setting and if the youth can start doing that and talk about it and females and males and the male asking female.

Change that social context.

\section{Dorcas}

Dorcas sticks to the fact that women need role models and mentors. Like Mercy, she sends a warning that "if they want to leave, they can leave." Women can only stay or pursue science if they are having fun.

\section{Mercy}

Mercy believes that we should let women be. Women should not be forced to study science because society wants them to. Women should be left to find their passion. According to Mercy "...we focus so hard on trying to get women into the field and get them to do this or that we just don't let them be who they are and that is a shame and it's sad." 


\section{Appendix C}

\section{Interview questions}

1. Could you tell me more about your academic background?

2. What do you do as a [name field]? And what are the values that are cherished in the field?

3. How long have you been practicing in your field?

4. How did you become interested in science? Can you give me a sketch of how everything happened?

5. Have you held any position(s) in your field? Could you name some?

6. In your view, what kind of qualities, attributes and skills does one need to succeed in your field?

7. As a woman, did you have to employ some strategies to succeed in the field and your position(s)?

8. What strategies have you used to succeed in your field? Or how did you succeed?

9. Could you describe a situation (experience) you encountered while pursuing your career or while serving a position in your field where you had to use a strategy to overcome that situation? Was the strategy effective?

10. How do you define processes and factors that have contributed to your successes?

11. I have read quite an amount of literature that point to the fact that men are more than women in science fields, how do you deal with that as a woman?

12. Sandra Harding (Philosopher of science) and Fox keller (Physicist) hold the view that structures that operate in science fields work against women. What do you think?

13. Other scholars also think that science and technology should be based on women values. Will that be possible?

14. Can you envision what would have happened if women were more than men in the field?

15. What are the social processes that lead women toward or away from careers in science and technology?

16. What can be done to encourage women to take up careers in science and technology fields?

17. What has been the most challenge for you as a woman scientist?

18. How did you overcome the challenge?

In some instances the questions changed to meet the needs of the moments and in other cases, more questions were asked based on the responses that the interviewees gave. 